\title{
What do police do and where do they do it?
}

\begin{abstract}
Recent research in the economics of policing has been concerned with what the police do and how much time they spend on those activities. Some of this research has highlighted that "crime" only consists of approximately 20 percent of police workload, based on the number of incidents, with much of the remaining 80 percent addressing public safety concerns. In this paper we decompose the nature of police incidents in a suburban city. We show that expenditures on policing, relative to the entire municipal budget, are relatively constant over 30 years and that the volume of police activity has remained relatively constant but with a slight increasing trend. We are able to show that the majority of the crime drop can be attributed to population growth in this suburban city and that the places in which they undertake different activities vary.
\end{abstract}

Keywords: economics of policing; police activity; crime; role of police. 


\section{Introduction}

Research using police data most often takes the form of analyzing actual criminal incidents; these analyses could be for the search of patterns over time or over space, victim patterns, or offender patterns. Recently, however, an increased interest has emerged with regard to what the police actually do. This research tends to all fall within the "economics of policing" research that is concerned with fiscal accountability, operational costs, operational accountability, increasing police resource demands, and decreasing police budgets (Griffiths et al., 2015). Though a large issue in and of itself (see Kempa 2014 and Public Safety Canada 2014 for issues and discussion points around the economics of policing), part of what is needed is more data in more contexts that speak to the issues of what police actually do in order to properly account for the "economics" of policing.

One aspect of this literature that needs to be addressed has been the concern over the percentage of time, resources, or calls for service to the police that actually involve criminal incidents. It is often cited that only 20 to 30 percent of police work, measured by call/incident volume or time spent, is related to criminal activity (Demers et al, 2007). Though this range has been called into question, it raises the issue of what police are supposed to be doing. A number of scholars have pointed out the great diversity in police work that extends well beyond actual criminal activity (Scott \& Goldstein, 2005; Her Majesty's Inspectorate of Constabulary, 2012; ICURS, 2014) and this appears to have generated questions regarding the increased need of publicly-funded police services.

Despite this concern, we need to consider the role of police in society. Though the expectations of the public with regard to the role of police in society has expanded beyond law enforcement over the years (Caputo \& McIntyre, 2015), the actual range of police work can 
officially be defined as wide in scope. For example, the Police Act in British Columbia ${ }^{1}$ lists the mandate of the police to: enforce the Criminal Code, enforce local by-laws, aid in the administration of justice, prevent crime, and maintain law and order. The first three of these activities are rather specific, but preventing crime and maintaining law and order can include a vast array of activities. In the case of rural and remote locations (and urban locations as first responders), a lack of social and health services means that the police must address these types of issues to maintain order; this is particularly true in cases that relate to mental health, an increasing concern for police (Vaughan et al., 2016). Maintaining law and order can obviously include the enforcement of the law, but it can also include responding to calls for police service that may lead to criminal events (HMIC, 2012). Order in society, however, can include much more than criminal violations or their potential: helping someone who is lost, directing traffic after a collision, and aiding in the negotiations between neighbors over some dispute, are but a few examples.

Though we do not discount the importance of understanding how much time police actually spend on activities directly related to crime, we investigate what the police do and where they do it in a small Canadian municipality. We use the set of police incidents, 2001 to 2014, to outline how police activities have evolved over time - these data do not include training, investigation, and court activities. We contribute to the economics of policing literature in a Canadian context by asking the following questions:

- Are expenditures on policing increasing?

- Has crime and the volume of calls for police service really dropped over time?

- Has the nature of what police do changed over time?

${ }^{1}$ http://www.bclaws.ca/civix/document/id/complete/statreg/96367_01 
- Are these activities in different places?

\section{Recent related research}

The contemporary research regarding the percentage of police work that relates to crime arguably begins with the Taking time for crime report out of the United Kingdom (HMIC, 2012) - see Webster (1970) and Reiss (1973) for classic research in this area, and an overview in Ryan (2003). In this report, the researchers wished to investigate the anecdotal claim that crime only consisted of approximately 20 percent of police work. Their analysis considered data from six police forces in the United Kingdom that ranged from urban to rural and indeed found that 28 percent of the incidents reported to the police were crime related. When they considered incidents that had the potential for crime (anti-social behavior, for example), they found that approximately 90 percent of incidents were related to crime and potential crime, consuming at least 80 percent of police time. Consequently, the vast majority of police activity was related to crime or some form of crime prevention, but also that criminal incidents occupy less time, on average, than other incidents.

The 20 percent claim emerged in Canada for the first time when Dale McFee, a former president of the Canadian Association of Chiefs of Police, stated that 70 to 80 percent of police calls for service were not related to criminal activity (McFee, 2013). This percentage was corroborated by Demers et al. (2007) who found that 24.1 percent of calls for police service were criminal incidents. Research in British Columbia has shown that approximately 30 percent of police incidents were related to criminal activity within the Royal Canadian Mounted Police (RCMP) jurisdictions in British Columbia (ICURS, 2014). This recent research in Canada, the United Kingdom, and the United States has all consistently shown that the percentage of criminal 
incidents is a relatively small component of police activities. As such, it proves to be instructive on how we view police activity and the use of their resources. Quite clearly from the available evidence, police are spending the vast majority of their time on crime and crime prevention; these are the activities that the public often considers to be their primary function. However, the official mandate of the police, particularly in British Columbia, is much broader than crime and crime prevention.

\section{Data}

The police incident data in the current analysis come from the Port Moody Police Department. Port Moody is a small municipality within Metro Vancouver. It is one of the Tri-Cities that includes, Port Moody, Coquitlam, and Port Coquitlam. Incorporated in 1913, Port Moody covers an area of just under 26 square kilometers (10 square miles) and has an estimated 2014 population of 34,000 .

The context of policing in Port Moody is shown in Table 1 and Figure 1. Port Moody has the lowest 2014 crime rate per 100,000 (total crime, violent crime, and property crime) in all of Metro Vancouver. In the Tri-Cities, Port Moody essentially has half the crime rates of Coquitlam and Port Coquitlam. With 1998 indexed to 100 in order to facilitate a trend comparison for all crime rates, Figure 1 shows there was a significant crime rate drop that is present in most countries around the world (Farrell et al., 2011). From 1998 to 2014, the total crime rate (excluding traffic) dropped 65 percent, with the violent crime rate dropping just over 70 percent and the property crime rate dropping just over 63 percent. It is in this context of dropping crime that questions are asked regarding the increasing expenditures on policing. 
Expenditures on policing relate to the costs of labor (salaries, benefits, sworn police officers and civilians), equipment, police expenditures per capita, total police expenditures, police expenditures relative to other government expenditures, and so on. In the analysis that follows, we consider the policing budget relative to the entire municipal budget (the share of the municipal budget) to evaluate policing expenditures. These data were obtained from Schedule 402 as published annually by the Local Government Division of the BC Ministry of Community, Sport, and Social Development. ${ }^{2}$ The statistics available include financial assets, liabilities, revenue, expenses, authorized debt, grants, and taxes information. All of these statistics schedules consist of data that have been provided to the Ministry by local governments in their annual financial reporting forms.

$<$ Insert Table 1 and Figure 1 About Here $>$

\section{Expenditures on policing}

The increasing expenditures on policing has been a concern in political circles (Federation of Canadian Municipalities, 2012a, b; Public Safety Canada, 2014), particularly within the fiscal constraints that have emerged in the past decade (Clarke, 2002; Lithopoulos \& Rigakos, 2005; Drummond, 2012; Public Safety Canada, 2014). But how much does policing cost? Kempa (2014) states that policing expenditures are 50 percent of municipal budgets. Due to the public nature of these expenditures, these figures are publicly available.

According to an Economics of Policing Report (ICURS, 2014), the 2014-2015 budget for the Ministry of Justice (BC) accounted for 3.54 percent of the Provincial budget; it is noteworthy that this includes policing, courts, and corrections. Even with a uniform distribution, this means

\footnotetext{
${ }^{2}$ http://www.cscd.gov.bc.ca/lgd/infra/statistics_index.htm
} 
that policing accounts for just over 1 percent of the Provincial budget. What about the other ministries? In the same budget year: Children and Family Development (4.16\%), Advanced Education (5.94\%), Social Development and Social Innovation (7.76\%), Education (16.5\%), and Health (51.9\%). Needless to say, policing consists of a small portion of the Provincial budget. What about increasing expenditures? At the municipal level, police expenditures per capita have increased 2.5 times from 1980 to 2010 , but school board expenditures have increased 2.04 times and health expenditures have increased 2.86 times. There are many factors that may be causing these increases (an aging population for increased health costs, for example), but the point is that yes expenditures on policing are increasing, but those increases are on par with other sectors of municipal expenditures.

Related to the rising expenditures on policing, the complexity of policing has also increased. According to Malm et al. (2005), from 1983 to 2003, there have been significant increases in the number of steps for handling cases leading to significant increases in the time necessary for those cases. For example, break and enters take 58 percent more time, driving under the influence is 250 percent more, and domestic assaults is 964 percent more. And it is reasonable to believe that handling these and other cases have not become less complex in recent years. It should be noted that this does not increase the expenditures on policing, per se, but limits the number of cases that can be investigated with existing resources.

Turning specifically to the municipal expenditures on policing, the Ministry of Community, Sport and Cultural Development, Local Government Statistics website publishes data that allow for the calculation of police expenditures from 1983 to 2014 . The percentages of the municipal budget spent on policing in Port Moody, Victoria, New Westminster, Surrey, Vancouver, and British Columbia as a whole are shown in Figure 2. Though somewhat volatile, 
it is clear that the percentage of the municipal budget spent on policing in Port Moody has fluctuated in between 17 and 21 percent for the past 30 years - this volatility emerges from changes in the total municipal budget rather than actual police expenditures from year to year. Moreover, the average range for the province of British Columbia over this time period is 14 to 18 percent and relatively constant. The other larger municipalities in the Metro Vancouver area all show similar percentages of expenditures on policing, some greater and some less than Port Moody. Overall, though this is a notable proportion of the municipal budget, it is no where near the high percentage put forth by Kempa (2014). We are not arguing that there are errors in previous research, but claims made for Canada as a whole do not hold up in British Columbia. $<$ Insert Figure 2 About Here $>$

So what do we know about the economics of policing? Policing expenditures are rising, but proportionately with other social services. Policing consumes approximately 1 percent of the Provincial budget in British Columbia. And despite any increases in the expenditures on policing, these expenditures have remained relatively stable, most often at or below 20 percent of the municipal budget for the past 30 years.

\section{Whither the "crime" drop}

In order to investigate the nature of policing in Port Moody, we will consider police incident data that spans 2001 to 2014; these data correspond to the rates and trends shown in Table 1 and Figure 1 - some, but not all, criminal incidents from these data end up in these statistics.

The trend in the police incident data is shown in Figure 3. Aside from the spike in 2002, and subsequent return to trend in 2003, there is an upward trend in police incidents in Port Moody. This trend is in contrast to the official crime statistics presented in Figure 1. Though not 
a significantly increasing trend over time, it is in stark contrast to the significant drop in "crime" over the same time period. This is a comparison of incidents to rates, but the counts of crime reported to Statistics Canada in Port Moody having also been falling from 35 to 40 percent, 2001 - 2014. When the incident rate is calculated, the drop is only 25 to 30 percent instead of 55 to 60 percent as reported in the official statistics. Given that the demand for police services is based on the volume of work assigned to the police, this shows why using the crime rate is problematic when considering police workload and corresponding budgets.

$<$ Insert Figure 3 About Here $>$

At this point we cannot differentiate why the trends of official crime rates and counts are divergent from the rates and counts of police incidents. As stated above, the number of official criminal incidents and the official crime rates for Port Moody are decreasing, but population increases may also be contributing to the "Crime drop". In fact, from 2001 to 2014, the population in Port Moody increased from 23,860 to 34,000 residents. This represents a 42.5 percent growth in the resident population. When taking this growth into account, almost one-half of the crime drop in Port Moody can be attributed to the increased resident population. With the relatively small volume of criminal activity in Port Moody, there would not have to be much of a decrease in actual criminal activity to have the drops in crime shown in Figure 1.

\section{The stability of what the police do}

In order to further investigate the nature of what the police do in Port Moody, police incidents are disaggregated into eight categories: violent crime, property crime, other crime, public safety and welfare, traffic, by-law enforcement, drugs and alcohol, and miscellaneous. These categories, particularly public safety and welfare, are comparable to the police study in the 
United Kingdom (HMIC, 2012). However, the list of incidents included is much broader than from the United Kingdom study; our list of incidents is available from the authors to the interested reader.

The breakdown of the various police incident types is shown in Table 2, with their trends in Figure 4. Despite a significant drop in Port Moody's violent crime rate from 1998 to 2014, there are very few of these criminal incidents in the city in any given year and most of these incidents are simple assaults. Moreover, the volume of these criminal incidents has been increasing slightly over the study period, not decreasing ${ }^{3}$. Property crime does show a modest decline that in conjunction with the resident population increase can easily explain the crime drop in Port Moody. And with the increases in police complexity, the police will not likely notice any decrease in their workload from these police incidents.

Most evident from Table 2 is that the vast majority of police incident activity is rooted in public safety and welfare. This is similar to previous research in this area (HMIC, 2012). As with this other research, this category includes: alarms, assist the public, suspicious person/activity, and assist another criminal justice or social service agency. These are all activities that easily fall under the mandate of maintain law and order, mentioned above with regard to the Police Act. Shown in Figure 4, the trends of violent crime and public safety and welfare are up, property

\footnotetext{
${ }^{3}$ The police incident dataset used within this analysis differs in some ways from official police records as reported to Statistics Canada. These incident data contain all records, founded or unfounded and, as such, may better represent actual police workload. However, it only considers the first (typically most serious) offence associated with each event. Official reports, in contrast, only contain founded events, and have varying protocols regarding event classification and reporting. As a result, some discrepancies will exist between official reports and police incident data.
} 
crime and other crime are down, by-law infractions are up, and the other categories are relatively stable.

\section{$<$ Insert Table 2 and Figure 4 About Here $>$}

In order to specifically address the percentage of police incidents that are criminal incidents, we present the percentages of the eight categories in overall police activity in Table 3 . Immediately obvious is that violent crime forms a very small percentage of what the police do, that has been relatively stable over the 14-year period. 13 to 28 percent of police incidents are identified as property crimes, but most often this number is below 20 percent. Moreover, the percentage has been decreasing over time and is below 15 percent in the most recent years. And other crime consistently forms a lower proportion of total police incidents than violent crime. Overall, criminal incidents total 20 to 30 percent of police incidents over the 14-year time period, consistent with previous research (HMIC, 2012; ICURS, 2014). Not surprising, based on the volumes shown in Table 2, public safety and welfare is the largest component of Port Moody police activity: 45 to 60 percent, most often at the higher end of that range. Though this activity quite often falls under the classification of "potential crime" (HMIC, 2012) with incidents such as alarm, civil/neighbor disputes, threats, and suspicious person/vehicle/circumstances, all of the incidents in this category easily fall under the maintenance of law and order within the Police Act. As such, consistent with previous research in this area, the police service in Port Moody is spending the vast majority of its efforts (over 90 percent of incidents, including traffic and bylaws) undertaking activities commonly associated with policing.

$<$ Insert Table 3 About Here $>$ 


\section{Locations of policing}

With knowledge of what the police are doing, knowing where they undertake those particular activities is of interest. In order to visualize where police activity is in Port Moody, kernel density maps (hot spot maps) are used — the most common form of visualizing hot spots of police activity. With eight classifications of police activity and 14 years of police data, the options for making maps are many. However, in the interests of brevity, we only map crime (violent crime, property crime, and other crime) and public safety and welfare considering all 14 years of data for each map —all incidents located at the police department have been removed to avoid mapping crime and public safety reporting. This is done for two reasons. First, with regard to the categories of police activity, crime and public safety and welfare consist of approximately 80 percent of police activity. As such, we argue that these categories represent the vast majority of police activity across the city. Second, with regard to the time frame, investigations into the yearly patterns of the kernel density maps provided qualitatively similar results to the maps shown below that capture all 14 years of data.

The kernel density map for criminal incidents is shown in Figure 5. The first aspect of this kernel density map to notice is the hot spot in the area called Newport Village. This is a mixed land use region of the city that contains restaurants, coffee shops, drinking establishments, shopping, and residential apartments. This is a region of high pedestrian traffic, a common aspect of places with (relatively) high levels of criminal activity (Andresen \& Jenion, 2010; Schmid, 1960a, 1960b). The other location marked on the map is the police department building that is located on St. John's Street, a major thoroughfare in Port Moody. Most of St. John's Street has a moderate density of police activity with the moderately higher density areas being associated with drinking establishments, a common result in the literature (Grubesic \& Pridemore, 2011). 
The remaining areas of Port Moody that have elevated levels of crime density are in a residential neighborhood to the west of St. John's Street.

\section{$<$ Insert Figure 5 About Here $>$}

Public safety and welfare incidents are mapped as a kernel density in Figure 6. Hot spots do emerge in Newport Village, similar to the kernel density map for criminal incidents. One location that emerges as a moderate density in Newport Village is the local hospital; this is likely because incidents get reported through the hospital, including mental health related calls for police service, not that the hospital is a location with many public safety issues. Of particular interest is the lesser degree of density of incidents along St John's Street than occurred for criminal incidents. Public safety and welfare incidents are still being identified with densities close to drinking establishments, but the general density along the entire east-west section of St. John's Street is not as apparent. Also notable is the low-moderate density to the northwest of the police department building. This location is a popular local park that includes walking paths, a playground, a water park, and a skate park.

\section{$<$ Insert Figure 6 About Here>}

Overall, based on Figures 5 and 6, public safety and welfare incidents do occur in the same places as criminal incidents. However, criminal incidents occur at many additional locations. Further investigations into the nuances of the individual incident types may prove to be instructive but are beyond the scope of the current analysis - there are over 500 incident call types over the course of the 14 years. 


\section{Conclusion}

Police provide a range of community-level services, extending beyond responses to crime and potential crime to include activities to maintain order within the community. As crime rates generally exhibit a decreasing trend in recent decades, understanding policing activities and associated expenditures is becoming a particularly relevant topic of study. This analysis explores the expenditures on policing, types of police activities, and locations of such activities within Port Moody, a smaller suburban municipality in the metropolitan Vancouver area.

Local findings have emphasized that while the absolute expenditures on policing is rising, this rise is in line with that of other social services. Over the past three decades, the proportion of municipal expenditures associated with policing have varied between 15 and 21 percent of the Port Moody municipal budget. When considering the policing activities associated with these expenditures, as measured with police incident data, it is clear that in contrast to significant drops in reported crime rates, local counts of police incidents generally follow a slight increasing trend. Further, when taking into account the strong population growth experienced within Port Moody, nearly one-half of the drop in the crime rate is associated with the increase in population base. The remaining crime drop can be largely accounted for by the moderate decline in property crime since 2001 . Given the considerable increase in police complexity identified in recent studies, the overall workload of the Port Moody Police is unlikely to be lessened by this reduction.

Overall, between 20 and 30 percent of all police incidents can be categorized as crime. Records relating to public safety and welfare form the largest component of police activities between 2001 and 2014; combined, the vast majority of Port Moody police incidents are associated with crime and crime prevention activities. Further, the spatial patterning of police 
incidents varies according to activity classification. Criminal incidents cluster primarily in areas with mixed land use and high levels of pedestrian access, while public safety and welfare incidents appear to be highly spatially concentrated, and may be over-represented at locations where incidents are likely to be reported or recorded, rather than locations where the incidents actually occurred. The breakdown of police activities in Port Moody is consistent with existing studies undertaken within both the UK and British Columbia, with a strong majority of the police workload relating to both crime and crime prevention. Future studies can benefit from exploring further sub-categories of police incidents, both across time and across space, to identify additional patterns within this locale and beyond. 


\section{References}

Andresen, M. A., \& Jenion, G. W. (2010). Ambient populations and the calculation of crime rates and risk. Security Journal, 23(2), 114-133.

Caputo, T., \& McIntyre, M. L. (2015). Addressing role and value in policing: toward a sustainable policing framework. Policing: An International Journal of Police Strategies \& Management, 38(2), 265-278.

Clarke, C. A. (2002). Between a rock and a hard place: RCMP organizational change. Policing: An International Journal of Police Strategies and Management, 25(1), $14-31$.

Demers, S., Palmer, A., \& Griffiths, C. T. (2007). Vancouver Police Department patrol deployment study. Vancouver, BC: Vancouver Police Department. Available at: http://vancouver.ca/police/assets/pdf/studies/vpd-study-patrol-deployment.pdf

Drummond, D. (2012). Commission on the reform of Ontario's public services. Public service for Ontarians: A Path to sustainability and excellence. The Drummond Report. Queen's Printer for Ontario, Toronto. Available at: www.fin.gov.on.ca/en/reformcommission/chapters/report.pdf (accessed 23 August 2017).

Federation of Canadian Municipalities (2012a). Towards equity and efficiency in policing: a report on policing roles, responsibilities and resources in Canada. Available at: www.fcm.ca/Documents/reports/Towards_Equity_and_Efficiency_in_Policing_EN.p df (accessed 23 August 2017).

Federation of Canadian Municipalities (2012b). Policy statement on community safety and crime prevention. Standing Committee on Community Safety and Crime Prevention. 
Available at: www.fcm.ca/Documents/corporate-resources/policystatements/Community_Safety_and_Crime_Prevention_Policy_Statement_EN.pdf (accessed 23 August 2017).

Griffiths, C. T., Pollard, N., \& Stamatakis, T. (2015). Assessing the effectiveness and efficiency of a police service: the analytics of operational reviews. Police Practice and Research, 16(2), 175-187.

Grubesic, T. H., \& Pridemore, W. (2011). Alcohol outlets and clusters of violence. International Journal of Health Geographics, 10(1), Article 1.

Her Majesty's Inspectorate of Constabulary (2012). Taking time for crime: A study of how police officers prevent crime in the field. London, UK: Her Majesty's Inspectorate of Constabulary.

Institute for Canadian Urban Research Studies (2014). Economics of policing: Complexity and costs in Canada, 2014. Burnaby, BC: Institute for Canadian Urban Research Studies.

Kempa, M. (2014). Understanding the historical relationship between economics and change in policing: a policy framework. Canadian Police College Discussion Paper Series.

Lithopoulos, S., \& Rigakos, G. S. (2005). Neo-liberalism, community, and police regionalization in Canada: A critical empirical analysis. Policing: An International Journal of Police Strategies \& Management, 28(2), 337-352.

McFee, D. (2013). Standing committee on public safety and national security. 41st Parliament, 1st session, January 31. Aavailable at: www.parl.gc.ca/HousePublications/Publication.aspx? 
DocId $1 / 45950911 \&$ Language $1 / 4$ E\&Mode $1 / 41 \#$ Int-7860663 (accessed 17 January 2017).

Malm, A., Pollard, N., Brantingham, P. J., Tinsley, P., Plecas, D., Brantingham, P. L., Cohen, I., \& Kinney, B. (2005). A 30 year analysis of police service delivery and costing: "E" Division. Burnaby, BC: Institute for Canadian Urban Research Studies.

Public Safety Canada (2014). The economics of policing. Available at: www.publicsafety.gc.ca/cnt/cntrng-crm/pleng/cnmcs-pleng/index-eng.aspx (accessed 23 August 2017).

Reiss, A. J., Jr. (1973). The police and the public. New Haven, CT: Yale University Press.

Ryan, J. F. (2003). Community policing and the impact of the COPS Program: A potential tool in the local war on terrorism. In A. R. Roberts (Ed.) Critical issues in crime and justice (2 ${ }^{\text {nd }}$ ed.) (pp. 134 - 147). Thousand Oaks, CA: Sage Publications.

Schmid, C. F. (1960a). Urban crime areas: Part I. American Sociological Review, 25(4), $527-542$.

Schmid, C. F. (1960b). Urban crime areas: Part II. American Sociological Review, 25(5), 655-678.

Scott, M. S., \& Goldstein, H. (2005). Shifting and sharing responsibility for public safety problems. Problem-Oriented Guides for Police Response Guide Series, No. 3. Washington, DC: US Department of Justice, Office of Community Oriented Policing Services.

Vaughan, A. D., Hewitt, A. N., Andresen, M. A., \& Brantingham, P. L. (2016). Exploring the role of the environmental context in the spatial distribution of calls-for-service associated with emotionally disturbed persons. Policing: A Journal of Policy and Practice, 10(2), 121 - 133. 
Webster, J.A. (1970). Police task and time study. Journal of Criminal Law, Criminology and Police Science, 61(1), $94-100$. 
Table 1. Metro Vancouver crime rates per 100,000; 2014

\begin{tabular}{|c|c|c|c|}
\hline Municipality & $\begin{array}{r}\text { Total } \\
\text { (excluding } \\
\text { traffic) }\end{array}$ & Violent & Property \\
\hline Surrey & 10143.77 & 1119.47 & 7013.15 \\
\hline Maple Ridge & 8602.26 & 1127.19 & 5231.8 \\
\hline Pitt Meadows & 8256.93 & 1059.94 & 5050.61 \\
\hline New Westminster & 8196.37 & 1246.81 & 5225.28 \\
\hline Langley & 7800.6 & 736.24 & 5808.25 \\
\hline Vancouver & 7576.99 & 1266.2 & 5664.3 \\
\hline Port Coquitlam & 6887.91 & 862.88 & 4245.44 \\
\hline North Vancouver City & 6714.54 & 933.44 & 3741.51 \\
\hline Burnaby & 6175.04 & 760.06 & 4883.73 \\
\hline Richmond & 6059.22 & 665.92 & 4257.84 \\
\hline Coquitlam & 5934.73 & 690.36 & 3949.57 \\
\hline Delta & 4915.49 & 548.76 & 3336.41 \\
\hline West Vancouver & 3686.34 & 553.05 & 2728.26 \\
\hline North Vancouver District & 3676.54 & 395.63 & 2537.58 \\
\hline Port Moody & 2973.47 & 337.37 & 2301.58 \\
\hline
\end{tabular}


Table 2. Port Moody Police Department, incident type counts, 2001 - 2014

\begin{tabular}{|c|c|c|c|c|c|c|c|c|c|c|c|c|c|c|}
\hline & 2001 & 2002 & 2003 & 2004 & 2005 & 2006 & 2007 & 2008 & 2009 & 2010 & 2011 & 2012 & 2013 & 2014 \\
\hline Violent crime & 137 & 156 & 125 & 143 & 126 & 123 & 132 & 124 & 165 & 224 & 174 & 189 & 192 & 147 \\
\hline Property crime & 1132 & 1287 & 1430 & 1563 & 1311 & 1424 & 1156 & 997 & 973 & 985 & 984 & 896 & 807 & 864 \\
\hline Other crime & 89 & 130 & 124 & 132 & 117 & 111 & 114 & 122 & 111 & 121 & 105 & 91 & 76 & 62 \\
\hline Public safety \& welfare & 3517 & 4521 & 2320 & 2682 & 2754 & 3087 & 2914 & 3352 & 3690 & 3448 & 3552 & 3542 & 3442 & 3632 \\
\hline Traffic & 564 & 746 & 571 & 657 & 649 & 686 & 662 & 739 & 715 & 751 & 762 & 684 & 752 & 664 \\
\hline By-laws & 156 & 202 & 74 & 84 & 83 & 171 & 133 & 203 & 280 & 388 & 388 & 346 & 361 & 319 \\
\hline Alcohol and drugs & 299 & 357 & 353 & 347 & 286 & 286 & 259 & 324 & 355 & 383 & 454 & 391 & 275 & 268 \\
\hline Miscellaneous & 115 & 133 & 176 & 237 & 181 & 175 & 173 & 220 & 252 & 198 & 120 & 113 & 104 & 117 \\
\hline
\end{tabular}


Table 3. Port Moody Police Department, incident type shares, 2001 - 2014

\begin{tabular}{|l|l|l|l|l|l|l|l|l|l|l|l|l|l|l|}
\hline & $\mathbf{2 0 0 1}$ & $\mathbf{2 0 0 2}$ & $\mathbf{2 0 0 3}$ & $\mathbf{2 0 0 4}$ & $\mathbf{2 0 0 5}$ & $\mathbf{2 0 0 6}$ & $\mathbf{2 0 0 7}$ & $\mathbf{2 0 0 8}$ & $\mathbf{2 0 0 9}$ & $\mathbf{2 0 1 0}$ & $\mathbf{2 0 1 1}$ & $\mathbf{2 0 1 2}$ & $\mathbf{2 0 1 3}$ & $\mathbf{2 0 1 4}$ \\
\hline Violent crime & 2.28 & 2.07 & 2.42 & 2.45 & 2.29 & 2.03 & 2.38 & 2.04 & 2.52 & 3.45 & 2.66 & 3.02 & 3.20 & 2.42 \\
\hline Property crime & 18.84 & 17.09 & 27.64 & 26.74 & 23.81 & 23.49 & 20.86 & 16.40 & 14.88 & 15.16 & 15.05 & 14.33 & 13.43 & 14.23 \\
\hline Other crime & 1.48 & 1.73 & 2.40 & 2.26 & 2.12 & 1.83 & 2.06 & 2.01 & 1.70 & 1.86 & 1.61 & 1.46 & 1.26 & 1.02 \\
\hline Public safety \& welfare & 58.53 & 60.02 & 44.85 & 45.89 & 50.01 & 50.92 & 52.57 & 55.12 & 56.41 & 53.06 & 54.32 & 56.65 & 57.28 & 59.81 \\
\hline Traffic & 9.39 & 9.90 & 11.04 & 11.24 & 11.79 & 11.31 & 11.94 & 12.15 & 10.93 & 11.56 & 11.65 & 10.94 & 12.51 & 10.93 \\
\hline By-laws & 2.60 & 2.68 & 1.43 & 1.44 & 1.51 & 2.82 & 2.40 & 3.34 & 4.28 & 5.97 & 5.93 & 5.53 & 6.01 & 5.25 \\
\hline Alcohol and drugs & 4.98 & 4.74 & 6.82 & 5.94 & 5.19 & 4.72 & 4.67 & 5.33 & 5.43 & 5.89 & 6.94 & 6.25 & 4.58 & 4.41 \\
\hline Miscellaneous & 1.91 & 1.77 & 3.40 & 4.05 & 3.29 & 2.89 & 3.12 & 3.62 & 3.85 & 3.05 & 1.84 & 1.81 & 1.73 & 1.93 \\
\hline
\end{tabular}


Figure 1. Crime trends in Port Moody, 1998 - 2014

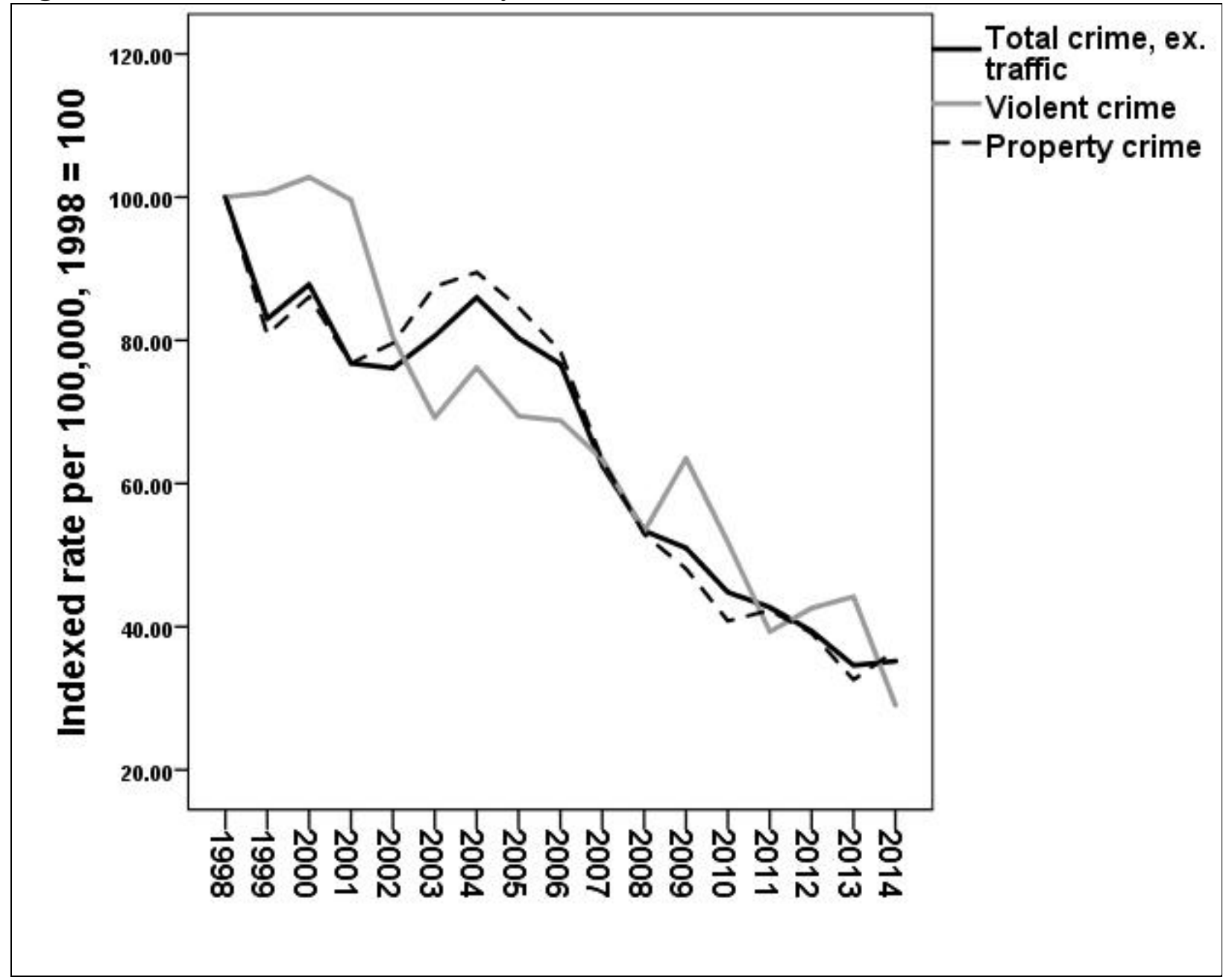


Figure 2. Port Moody Police Department, share of municipal budget, 1983 - 2014

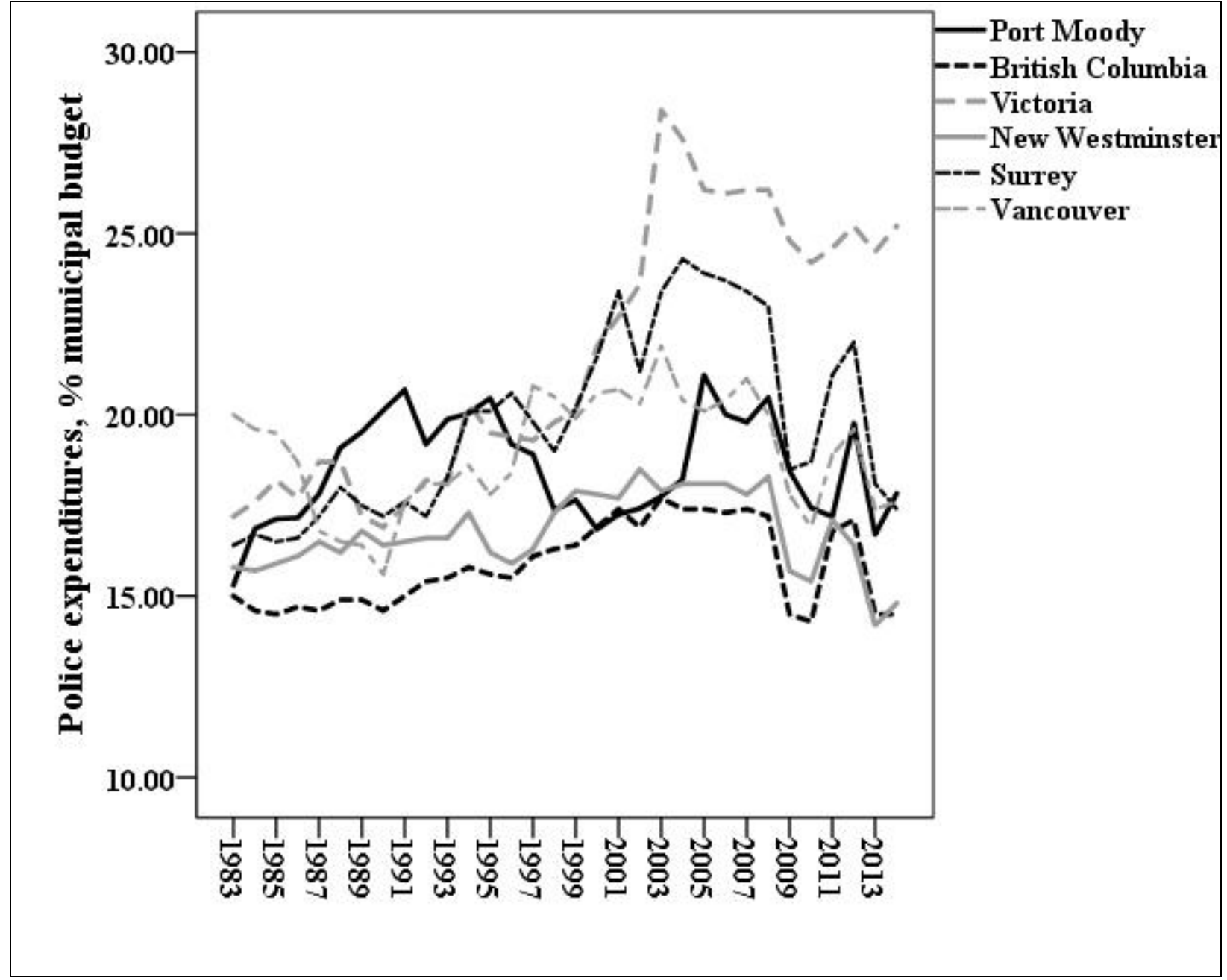


Figure 3. Port Moody Police Department, incidents, 2001 - 2014

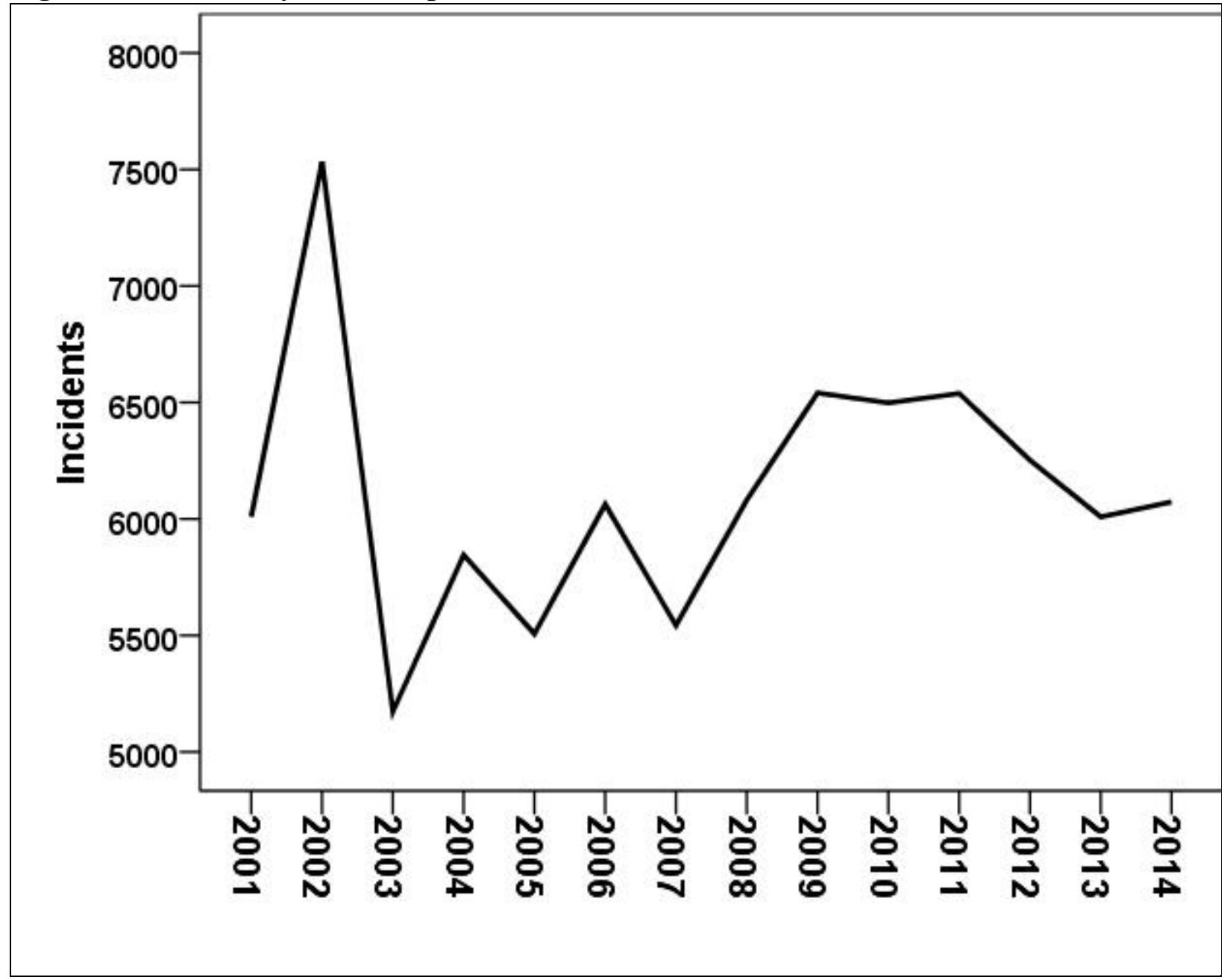


Figure 4. Port Moody Police Department, incident type trends, 2001 - 2014

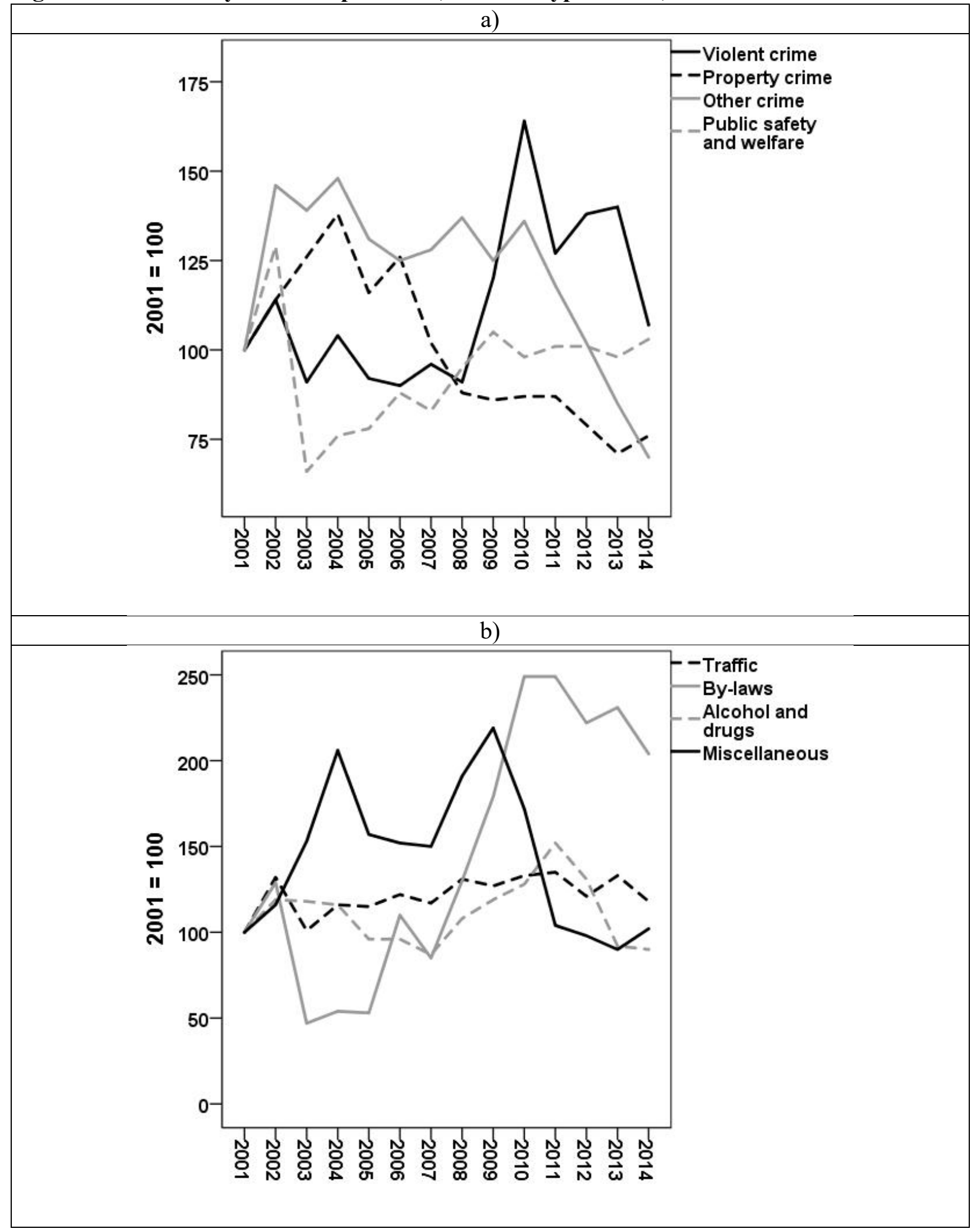


Figure 5. Criminal incidents kernel density, Port Moody, 2001 - 2014

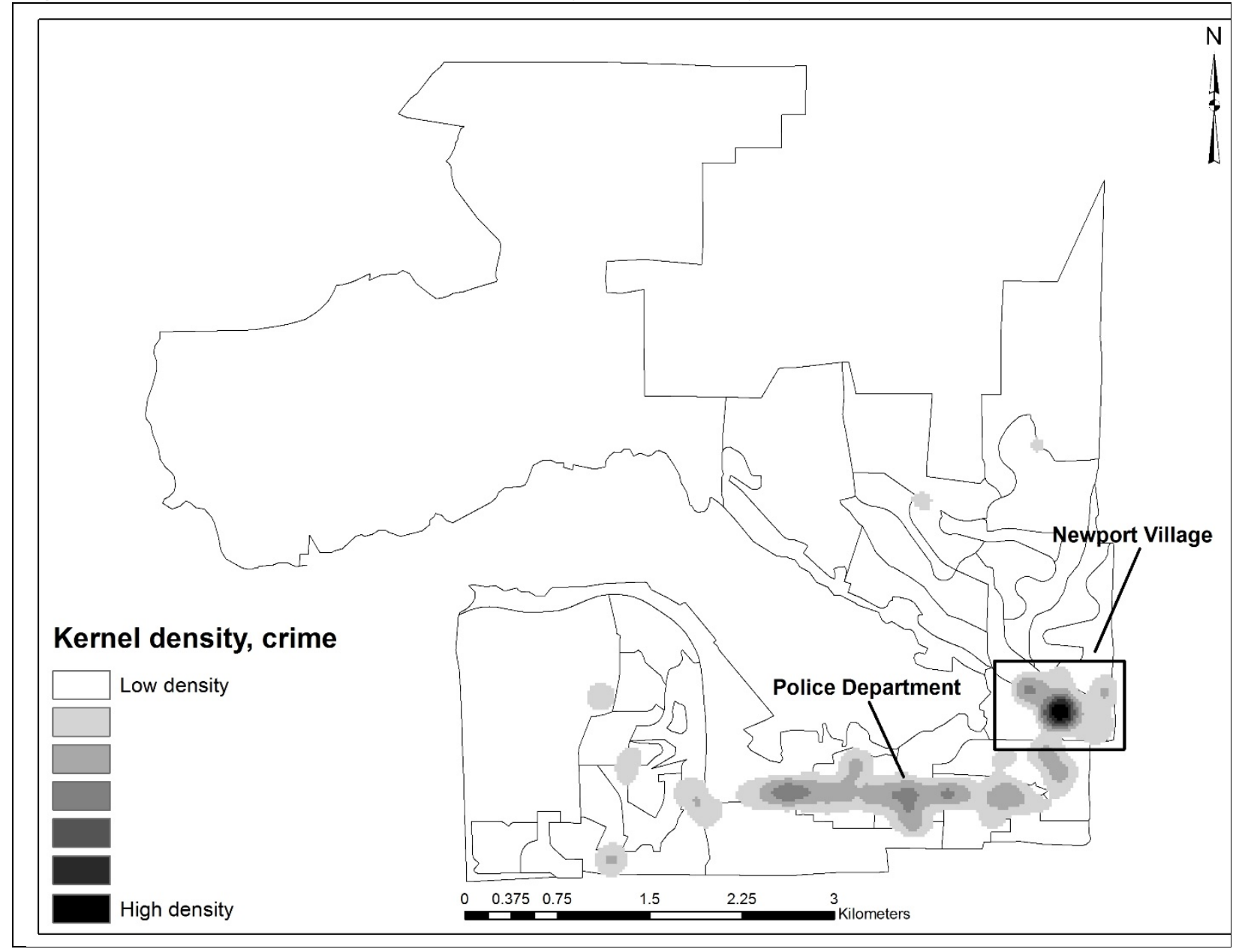


Figure 6. Public safety and welfare kernel density, Port Moody, 2001 - 2014

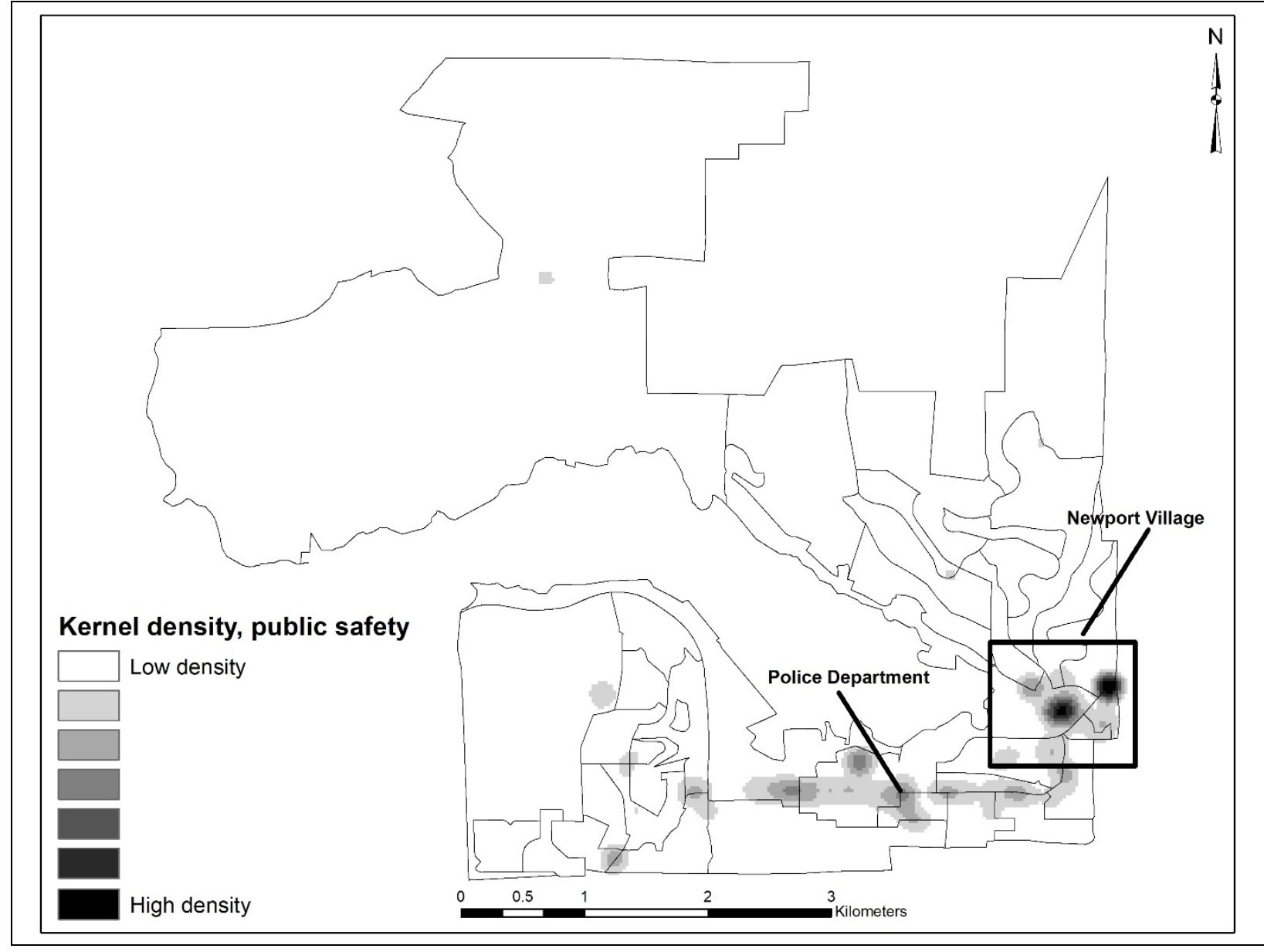

